\title{
Sociolinguistics of the Varieties of West African Pidgin
}

\section{Englishes-A Review}

\author{
Edward Owusu $^{1,3^{*}}$, Samuel Kyei Adoma ${ }^{1} \&$ Daniel Oti Aboagye ${ }^{2}$ \\ ${ }^{1}$ Department of Communication Studies, Sunyani Technical University, Sunyani, Ghana \\ ${ }^{2}$ Counselling Unit, Sunyani Technical University, Sunyani, Ghana \\ ${ }^{3}$ Department of Linguistics, University of Ghana, Legon, Ghana \\ *Edward Owusu, E-mail: edwardowusu@minister.com
}

Received: October 26, 2016

Accepted: November 6, 2016 Online Published: November 13, 2016

doi:10.22158/selt.v4n4p534

URL: http://dx.doi.org/10.22158/selt.v4n4p534

\begin{abstract}
Language contact is a key issue in the field of sociolinguistics. One notable phenomenon in the field of language contact is Pidgin English. Historically, Pidgin began as a language marked by traditional interference used chiefly by the prosperous and privileged sections of a community, represented by the unskilled and illiterate class of the society (Quirk et al., 1985). However, nowadays, it has gained status in some communities to the extent that it has become the mother-tongue of such communities. This paper, therefore, investigates the sociolinguistics of the multiplicity of West African Pidgins of Cameroon, Nigeria and Ghana against some sociolinguistic variables of gender, attitudes, code switching, borrowing, slang, and domains of language use. The paper has been structured into two main parts. The first section contains the reviews/synopses of the various papers or works that have been used for the study. The second section deals with a discussion on the prominent sociolinguistic variables found in the various papers.
\end{abstract}

\section{Keywords}

Pidgin English, Nigerian Pidgin English, Ghanaian Pidgin English, Cameroon Pidgin English, sociolinguistics, attitude, code switching, domains of language use

\section{Introduction and Background}

Several language contact phenomena abound; and pidgin is one of them. A pidgin is a lingua franca which arises in order to assist communication between speakers of dissimilar languages who are in continued contact with each other for a purpose, e.g., in trade or plantation situations (Rickford, 1991). It thus, involves a combination of two or more languages. Decamp (1987, p. 175) on his part describes pidgin as an "incidental communication language within a multilingual setting which is the native language of nobody". Pidgin, hence, normally exists in multilingual environments. To Edwards (1994, 
p. 42), it is a baby-like and rather superficial repetitions associated with trade communication. An example of a prominent English-based pidgin is Tok Pisin (Note 1). In West African, many examples exist: Ghanaian Pidgin English (GhaPE/GhPE), Nigerian Pidgin English (NE/NPE), Cameroon Pidgin English (CPE/CamP), and Liberian Pidgin English. A Creole, on the other hand, is a native or first language or mother tongue for its speakers, as in the case of children born to pidgin-speaking grown-ups on a farm (Rickford, 1991). Thus, Creole is used to replace the native language in a micro-speech community (Quirk et al., 1985, p. 84). Some popular Creoles are: West Caribbean Creole English, Trinidad Creole French, Krio (Note 2) and Sango (Note 3). Because of the influence they exert on societies, Pidgins and Creoles are of considerable interest to many sociolinguists across the globe. Most of these sociolinguists (see Akinnaso, 1989; Bamgbose, 1982; Huber, 1999; Dako, 2002) view this phenomenon as a positive thing that has the propensity of boosting easy acquisition of language. Others (for example, Brann, 1985; Elugbe, 1995), however, describe it as desecrated form of language; since it has the inclination of affecting one's proficiency of the Standard Form. This work is hence, a comparative study of the sociolinguistic factors of the various West African Pidgin Englishes.

\section{Summary of Papers}

\subsection{Ideologies and Attitudes towards Pidgin English in Cameroon-Abongdia (2014)}

In Ideologies and Attitudes towards Pidgin English in Cameroon-Abongdia (2014) discusses language ideologies and attitudes of students from University of Yaoundé 1 (one of the finest universities in Cameroon) about Pidgin English. Cameroon is a linguistically diverse country with about 280 local languages spoken (Anchimbe, 2006). This linguistically complex nature of Cameroon has made it difficult for any of the local languages to be used as a national language. Cameroon was colonised by Germany in 1884. However, when it (Germany) lost the First World War in 1918, its colonial possessions were handed over to the victors-France and Britain (Abongdia, 2014). Cameroonians were then expected to speak English and French. The 1961 constitution of the country consequently, made French and English the official languages: French for the Federal state of East Cameroon and English for that of West Cameroon (Abongdia, 2014). These two languages were adopted for fear of future tension from any of the groups. The adoption of French and English as the two official languages of Cameroon gave birth to two peculiar linguistic markers: Francophone and Anglophone Cameroonians (Abongdia, 2014). While French became the lingua franca in the French speaking part of Cameroon, Cameroonian Pidgin English (CPE) was used in the English speaking part (Abongdia, 2014). The other lingua franca used is Camfran-anglais (CFA), a hip-hop language variety which emerged from CPE, English and French (Abongdia, 2014). This language, which is a mixture of English and sometimes pidgin, is normally used by people who are not fluent or who have some communication difficulty with both French and English (Abongdia, 2014). The qualitative data for this paper was collected by means of open-ended questions on questionnaires, face-to-face interviews, as well as observations. The participants-lecturers from the Linguistics and English departments; and 3rd 
year linguistic students-were sampled from University of Yaoundé 1, Cameroon. The sample size for the study was 75 participants (60 students and 15 lecturers). These respondents were made to fill questionnaires. Again, one-on-one interview session was conducted with unspecified number of the respondents; and observations on the use of different language varieties by the different groups within the University community were done. The work investigated the role and status of Cameroon Pidgin English (CPE) and the ideologies and attitudes the indigenes hold towards this language. Respondents were found to have both positive and negative attitudes towards CPE; but the number of the participants who responded in the affirmative outweighed that of those who responded in the negative. Furthermore, the observation the writer did, corroborated the fact that a lot of the Anglophones used $\mathrm{CPE}$ for their interaction with one another as a language of socialisation. For example, most students were found using it in lecture sessions and during group discussions. But there were mixed reactions from the interview conducted. Majority of the students appeared to have positive attitudes towards this variety:

1. It is good for socialisation and familiarity (Francophone male student).

2. They are used when we are with friends or when we are in the family. They serve as means of creating an intimate relationship (Anglophone male student).

3. I think we should create our own languages which express properly what we are and our reality (Anglophone male student).

4. I think that for Pidgin English for example in the North province, all grandmothers and fathers speak it... (Francophone male student).

The minority of them on the other hand, did not pass any good comment about the variety:

1. It is not the language of the world and therefore limits studies.

2. There are no documents in these languages.

This study is significant since it is one of the works done on the attitudes of Cameroonians towards CPE and CFA. Perhaps, without such a study, debates on CPE would have lost empirical grounding. Most people would have concluded that since the greater population of Cameroonians uses this variety, attitudes are generally positive. The paper has thus, revealed that attitudes towards Cameroonian Pidgin English are not generally positive as some students passed several negative comments on CPE and CFA as a whole. Again, the strength of the paper is based on the in-depth theoretical and conceptual frameworks used; which were subsequently employed strongly in the discussions of the findings of the work. Two of such frameworks are Kroskristy's (2000) concept of language ideology, and Weber and Horner's (2012) five major language ideology concepts. However, the researcher, Abongdia (2006), failed to make his study practical-oriented. Thus, for a study on new Englishes (i.e., CPE), one would have expected the writer to include some CPE sentences or examples that participants produced. For example, on his observation of the participants, he has reported that the students were heard using CPE in "lectures and during group studies" but no practical examples of such productions were cited. 
2.2 Cameroon Pidgin English (CPE) as a Tool for Empowerment and National Development-Neba et al. (2006)

The paper examines the need for Cameroon Pidgin English (CPE) to be adopted as a pedagogical language in both cities and other urban centres in Cameroon. This, according to the writers is necessary, taking into consideration the linguistic situation of Cameroon. Cameroon has about 286 languages (Neba et al., 2006), with none of these being considered as natural indigenous languages that serve as Languages of Wider Communication (LWCs) as Hausa, Igbo, and Yoruba do in Nigeria (Neba et al., 2006). It has been envisaged that the use of Mother Tongues (MTs) in education has the propensity of degenerating into ethnic rivalry, ethnic animosities, and conflicts that could lead to national disintegration. This is so, especially where one particular language within the cluster of languages is chosen as the language for pedagogical studies. One way of resolving such a problem, according to the writers, is to resort to standard creation which refers to choosing one language that could serve as a bridge for the other languages. Luckily for Cameroon, CPE is one language that almost all and sundry speaks (Neba et al., 2006). It is no longer a makeshift language; and has grown to maturity as a language that can satisfy the complex linguistic needs of Cameroon (Ayafor, 2006, p. 6). The language has been creolized and is subsequently, the mother tongue of most Cameroonian indigenes. This creolisation should be seen as a blessing and not a curse. Therefore, if CPE is adopted, no ethnic rivalry would emerge and the problem of cost associated with developing a language into a national language would be missing. Ayafor (2006) drawing inspiration from Schneider (1963), Todd (1990), Ayafor (1996), McArthur (1998) and Ayafor (2000) has argued that CPE should no longer be called Pidgin English but rather "Kamtok (Note 4)". Neba et al. (2006) have again argued that CPE is an African language and not a version of English. Therefore, its use cannot defeat the purpose of education as many have argued. For example; tense, aspect and mood in English are depicted in the alteration of the form of the verb; but in CPE, this is marked by tonal patterns as is the case in most African languages including Cameroonian indigenous languages:

\section{CPE}

(i) $i$ kâm

he come

(ii) $i \quad b i \quad k a ̂ m$

he Past come
2. Bafut (Note 5)

(i) $\grave{a} z \hat{\imath}$

he come

\section{English}

(i) he comes

Neba et al. (2006).

The example illustration above clearly shows that CPE is exactly like Bafut (in terms of formation of the present and past forms of the verb) but differs from English. The paper has revealed that English is the lexifier of $\mathrm{CPE}$, but the language (CPE) has adopted the syntax of African language. Also, CPE is a major lingua franca; hence, its use as the language of education would not be a problem. However, Neba et al. (2006) have recognized some potential problems that are likely to be encountered in the process of this standardization and adoption. The first one is the problem of acceptability. Many people 
who have the notion that $\mathrm{CPE}$ has a negative impact on the English language may resist such a policy. Two, CPE has multiplicity of dialects; therefore, having a common orthography for it would be problematic.

\subsection{Student Pidgin (SP): The Language of the Educated Male Elite—Dako (2002)}

Dako's (2002) paper, Student Pidgin: The language of the educated male elite, highlights the major characteristics of Student Pidgin (SP) in Ghana which make SP differ from Ghanaian Pidgin (GhaPE). According to her, SP was spawned about thirty years ago in secondary schools and the nation's (Ghana) five main traditional universities; and has gradually developed into an extended pidgin (student pidgin) and is mainly spoken by male students for their out-of-classroom conversation (Dako, 2002). The paper draws its methodological strength from the secondary data of Tawiah (1998), Dako (1999), Huber (1999) and Nettey (2001). Out of 50 male students randomly selected from the University of Ghana's Halls of Residence, 47 said they spoke SP while 3 did not speak it (Tawiah, 1998; cited in Dako, 2002). Also, out of 50 female students randomly selected, only 3 admitted knowledge of SP and this makes SP a gender bias language (Dako, 1999; as cited in Dako, 2002). The work touches on three main linguistic phenomena-lexis, code switching and structure - of SP. On lexis and code switching, it came to light that SP makes itself as different from GhaPE by not using distinctive pidgin words; and it (SP) also exhibits a different vocabulary from GhaPE as code switching (predominantly Twi, Ga, and SE) and borrowing is much more noticeable. Also, the paper has revealed that structure-wise, SP differs from GhaPE. In fact, about $65 \%$ of the work is on these structural differences. Dako has cited several examples of such structural changes from Huber (1999):

1. The negative-completive function of neva is virtually non-existent in GhaP, but is a prominent feature in SP:

- a neva gə fəget I'll not forget

- $\quad$ i neva bi i sista she is definitely not his sister.+

2. The use of 3rd person plural $d \varepsilon m$ ( they) rather than the GhaP dei

- $\quad$ den do dem wan, wan, wan.

Then do them one at a time.

3. The use of the Akan negative emphatic to suggest something inexcusable: kura: (at all): $20 \mathrm{~K}$ dic I no gud kura: twenty thousand isn't good at all.

The paper is significant as far as knowledge contribution (in the area of new Englishes) is concerned. It has made us to realize how SP varies from GhaPE in the areas of lexis, code switching and structure. Apparently, hitherto, they were all assumed to possess the same features. For example, it has been revealed that SP is mainly used by male students. Again, the strength of the paper is firmly rooted in Huber (1999) as GhaPE has been juxtaposed against SP. However, for such a revelation like this, the writer should have come out with her own working definition for SP. This is not explicitly done. But, on the subsection, what is $S P$ ? We have been made to understand that defining Student Pidgin is problematic; hence several ideas/points have been used in explaining SP. 
2.4 Investigating the History of Pidgin English: Early Highlife Recordings from Ghana-Schmidt and Huber (2011)

The study traces the history of Pidgin English in the early Ghanaian highlife recordings. The paper opens with an introduction of Pidgins/Creoles which they claim are mostly based on sociohistorical outlines from a macro-sociolinguistics perspective. According to them, they are very few studies on Pidgins and Creoles which are based on actual language recordings. However, the writers, Schmidt and Huber (2011), have cited few works which also investigate song lyrics: Trudgill (1983), Kreyer and Mukherjee (2007), Brato and Jansen (2008), Miethaner (2005), and Coester (1998). The main argument of the paper is that GhPE, which is part of the West African Pidgin and Creole dialect cluster, is used by smaller section of the Ghanaian society, has limited functional domains, and is more stigmatized than pidgins in Nigeria and Cameroon. Again, the paper holds that GhaPE is not homegrown but was imported from Nigeria (Amoako, 1992) and has existed in most popular Highlife songs in Ghana. This includes popular dance music, African-Western fusion style songs (Collins, 1989), and palm-wine Highlife. Specific examples of songs with GhaPE or musicians/bands who have incorporated GhaPE in their works are Emmanuel Tetteh Mensah, Tempos Band, King Bruce and Black Beats' "The Queen's Visit", the Red Spots Band's "Coffee and Tea". Some sociolinguistic factors identified in the Highlife songs used are code-switching, borrowing, and gender.

2.5 The Sociolinguistics of Nigerian Pidgin English in Selected University Campuses in Nigeria-Abdullahi-Idiagbon (2010)

This paper investigates the diversities of the Nigerian Pidgin English (NPE). A special attention is given to the variety being used on the Nigerian university campuses. Nigerian Pidgin or Nigerian Pidgin English (NigP/NPE) (which is also referred to as Pidgin, Broken English or Broken) is an English-based pidgin spoken as a kind of lingua franca across Nigeria. It has as its superstrate, English, with Igbo, Yoruba, and Hausa being its substrate (Abdullahi-Idiagbon, 2010). Nigerian Pidgin, according to Ihimere (2006, p. 296), has become the native language of almost 3-5 million Nigerians, and a second language for at least another 75 million. The author, Abdullahi-Idiagbon, has highlighted five different variants of NPE: Bendel, Calabar, Lagos, Kano/Maiduguri and Port Harcourt variants. The participants for the study were drawn from six Nigerian University campuses: Bayero University, Kano (BUK); Ahmadu Bello University, Zaria (ABU); University of Lagos, Lagos (UNILAG); University of Ibadan, Ibadan (UI); Imo State University, Owerri and University of Nigeria, Nsukka (UNN). The sample size for the study was 1000 participants (i.e., 200 respondents were selected from each of the five schools). Questionnaires and oral interviews were the two main instruments used in collecting primary data for the paper. The primary data collected were descriptively analyzed. The research showed that NPE can be categorized into three: (1) Ordinary NPE spoken by the enormous majority of Nigerian People; (2) Wafe-rank, a special variety popular among the Nigerian students; and (3) Hooligan's version popularly associated with the touts, area boys or hoodlums (Abdullahi-Idiagbon, 2010). Again, NPE was found to be highly characteristic of some sociolinguistic phenomena such as 
borrowing, code switching, and slang. The paper contributes to knowledge in several ways. Drawing on Obiechnina's (1984) classifications of the variants of NPE, the writer has given a diagrammatic picture of the five variants identified. For example, the Lagos variant has South-West, Eastern part and South-Central sub-variant of NPE. Furthermore, the paper is well stocked with diverse examples on the sociolinguistic issues discussed: code switching/code mixing, borrowing, slang, language identity, and NPE variants. Nevertheless, one noticeable characteristic of the paper is its chaotic arrangement of the sections.

\subsection{Communication Problems of Nigerian Pidgin Speakers-Ndimele (2011)}

The paper investigates the communication problems of speakers of Nigerian Pidgin English (NPE). Three problem areas - lack of educational status, lack of a standard orthography, and lack of cultural attachment — have been discussed. All these predicaments of the NPE speaker (according to the writer) affect the social acceptability of NPE. The main argument of the paper is that though NP is not used officially in education, it has found its footing in some domains in Nigerian such as literature, music, media, advertisement, and government. For example, there is a radio station-WAZOBIA FM (Note 6), Port Harcourt, and Lagos - that has been dedicated to NP only. Again, "most 'catchy' advertisements (oral and written) are done in NP" (Ndimele, 2011). But in spite of all this gradual ascendancy in these domains, NP/NPE is still stigmatized. Most indigenes who have complex attitudes towards the use of NP believe that it is the corrupt version of Standard English. Meanwhile, because of the linguistic complexity of Nigeria, most ethnically heterogeneous areas such as Warri, Sapele, Port Harcourt, Lagos, and Abuja use NP as a lingua franca. NP is thus the native language to approximately 3-5 million people in Nigeria. Also, it is the second language for another 75 million Nigerians (Wikipedia.org as cited in Ndimele, 2011). The writer concludes by stressing the fact that the "Nigerian linguistic situation would have been more complex and chaotic without the emergence of NP" (Ndimele, 2011). Accordingly, measures should be put in place to ensure that these communication problems of NP speakers are dealt with; so that NP could become the official L1 of at least the most linguistically heterogeneous states like Rivers, Delta and Edo (Ndimele, 2011). Thus, the status of NP could be lifted to be at par with the three major languages-Hausa, Igbo, and Yoruba. The writer has recommended that "government can encourage the use of NP in State Houses of Assembly; especially in linguistically mixed states" as is the case in Papua New Guinea where Tok Pisin (an English based pidgin) is now used in the House of Assembly (Ndimele, 2011). A recommendation has also been made about the fact that an Advisory Board or Committee should be instituted to develop a programme that will evolve in stages for this cause - official standardization and adoption of NP as one of the main languages. However, for such a study, the writer should have collected some primary data to confirm or disconfirm her stance of the matter. For example, a primary data collected from a linguistically diverse state such as Rivers, Delta and Edo States would have served as basis for the main argument made. 


\subsection{Nigerian Pidgin and West African Pidgins: A Sociolinguistic Perspective-Ofulue (2011)}

This paper juxtaposes Nigerian Pidgin English and West African Pidgins against some sociolinguistic variables. The varieties spoken in Nigeria, Ghana and Cameroon constitute the focus of the paper. The comparative analysis focuses on sociolinguistic factors such as attitudes, functions, domains of use and language use. Data used were sampled from WAZOBIA Facebook Discussion Board. Again, a sampled text on a news item, Una World News, was used as a primary data for the study. Apart from these data, several secondary sources of data were incorporated in the study. Key among them includes Huber (1999), Amoako (1992), Deubar (2005), Mbassi-Manga (1973), and Schröder (2003). On structural differences and similarities, the paper discovered that Nigerian Pidgin (NP) and Cameroonian Pidgin (CamP) share the same completive marker-don, copula — na, and plural marker-dem. Some of these structural similarities are however, missing in Ghanaian Pidgin (GhaP); except for the copula where GhaP uses $b i$ instead of $n a$ as seen in both NP and CamP. On attitudes, it came to light that the degree of stigmatization is high in GhaP as compared to CamP and NP where the degree is medium and low respectively (Ofulue, 2011). The strength of the paper lies in its comprehensive comparative analysis of the three varieties in terms of the sociolinguistic variables-language use, language development, attitudes, functions, domains of use, codification and elaboration and modernization-studied. However, the study would have been more comprehensive if the writer had included another West African state that speaks pidgin.

2.8 Ghanaian Pidgin English in Its West African Context: A Socio-Historical and Structural Analysis by Magnus Huber-Andrei A. Avram (2003)

This paper is a review of Huber (1999), a comprehensive book on Ghanaian Pidgin English. The book is a remarkable addition to the general literature on pidgin and creole languages. The book, which is divided into seven chapters, investigates the diachrony and synchrony of Ghanaian Pidgin English (GhaPE), an area which has received less attention. The first chapter, introduction, consists of a short assessment of the literature on GhaPE and a discussion of the nature of the experimental data analysed, the size of the corpus, and the methodology of the fieldwork. As chapters two to four are dedicated to the West African Pidgin Englishes and (WAPEs) Krio, chapters five and six are concerned with the synchrony of GhaPE. Specifically, five examines the sociolinguistics of GhaPE. Here, two main varieties are identified - educated GhaPE and uneducated GhaPE. Six is further dedicated to the two main varieties of GhaPE: basilectal (associated with the less educated people), and mesolectal/acrolectal GhaPE (associated with students). Chapter seven, conclusion, summarizes the main findings of the study.

\section{Sociolinguistics of West African Pidgin Englishes}

The field of sociolinguistics has to do with language use as a social occurrence and, where probable, it tries to establish causal relationship between language and society (Coulmas, 1997; Hudson, 1990; and Holmes, 2001). Some of the variables of sociolinguistics include language use, domains, gender, age, 
code switching, ethnicity, social class and attitudes. This paper reviews the sociolinguistic variables - code switching, borrowing, slang, gender, attitudes, and domains and language use - in the papers under study:

3.1 Code Switching, Slang and Borrowing.

Dako (2002) citing Nettey (2001, pp. 37-38), has projected a conversation that code switches between SP, Ga, Fanti and SE: [Key: SP=italics, Ga: italics underlined, SE: bold, Fanti: bold intalics].

A: jú brodás, jú hé wat de go on fo de skúl insáid?

You brothers, have you heard what is going on in the school?

B: Wát bi dát? What is it?

C: Àlí Bàbá im mata? $\quad$ Ali Baba’s case?

A: $J \varepsilon-b a d \varepsilon$ mã nó trai. Yes, but that is a bad thing that he did.

A: Àsomua: julo ni.

Apparently ([English loanward <assume> in Ga] he is a thief).

C: $\underline{B \varepsilon}$ danć: $\underline{k o j o} \underline{k \varepsilon \rho}$ ? Doesn't Kojo always say so?

A: But $\underline{\varepsilon n \varepsilon} \underline{\underline{l}} \underline{\underline{\varepsilon}}$ : bad. $\quad$ But this is bad. Nettey (2001); cited in Dako (2002).

Again, Dako (2002) has pointed out that SE vocabulary from domains not usually associated with Pidgin and salient use of English function words are observed in the some exchanges (Dako, 2002, p. 56). Two of such exchanges are:

A: Ju liv in hegemony wei ju no no.

You live in hegemony, and you don't know it.

B: Wi $n \supset d \varepsilon$ tวk about hegemony $f \supset h \varepsilon$, wi $d \varepsilon$ tวk about corrupt political leaders who are amassing wealth.

We are not talking about hegemony, we are taking about corrupt political leaders who are amassing wealth.

Schmidt and Huber (2011) have established that some structures on code-switching and borrowing are the same in StE and GhaPE. In the lyrical example below, the underlined transliterated structures are common in both StE and GhaPE:

I give my money to my wife

For make me chop $(x 3)$

That time I return back from business

My wife run away...

Abdullahi-Idiagbon (2010) has also maintained that considerable number of Yoruba words and slangs can be found in NPE:

1. Wetin be your logo (identify yourself/who are you?)

2. The guy don gaz (the man is dead)

3. $\quad$ Shine your eye well (be careful!)

NPE, according to Abdullahi-Idiagbon (2010), is also highly characteristic of borrowing and 
code-mixing. It is therefore not uncommon to hear Hausas in Bayero University, Kano or Ahmadu Bello University, Zaria, code-mixed with Yoruba or Igbo language:

1. Yawa don gaz (trouble has come)—Hausa

2. Za mu tafi if you no come back on time (We shall leave if you don't return on time)—Hausa

3. $\quad$ Biko see me see trouble (please, bail me out of this conspiracy)—Igbo

4. $\quad$ Chineke sebi sey my hand no dey (God knows that I know nothing about it)—Igbo

5. These girls don jag an (These girls are flirts)—Yoruba

6. My phone don lana (My phone is faulty) —Yoruba

\subsection{Attitudes}

Generally, most people have intricate attitudes towards the use of pidgins; in that, they see it as a debased or corrupt version of standard languages (Ndimele, 2011). According to Elugbe and Omamor (1991, p. 142) most educated Nigerians believe that NP is inferior Standard English. Therefore, they try to prevent their children from speaking it. Igboanusi (2001, p. 362) has reported that "Nigerian Pidgin lies in its image as 'bad' form of English". Elugbe and Omamor (1991, p. 362) have maintained that although, linguists have recommended the approval of NP as Nigeria's official lingua franca, they are quick to indicate that the lack of status of NP has to do with the fact that the ability to speak it presents no social advantage on the part of the speaker. Thus, the language is stigmatized by some elements in Nigeria such as the educated and the elite. The attitude of most educated Nigerians concerning the use of NP can be likened to a chef in a five-star hotel who openly disregards roadside foods; but secretly patronizes these "junk foods" because they have irresistible taste (Ndimele, 2011). The educated and the elite Nigerians use NP for relaxation with their pals especially when their wards are not listening. Just like the chef in a five-star hotel, they have negative attitudes towards it; but they use is clandestinely. However, Jowitt (1990, p. 14) as quoted by Abdullahi-Idiagbon (2010) has remarked that NPE has attained the feat of dignity among both the illiterate and literate members of the society. He has noted that the use of pidgin indicates closeness and informality and, that it is good for cracking jokes. Thus, the attitudes of indigenous Nigerians about NPE are both positive and negative. The study of Abongdia (2014) revealed that attitudes of Cameroonians about CPE are mixed; though skewed towards one direction-positive. $73.3 \%$ of the respondents reported that they communicate in both $\mathrm{CPE}$ and CFA. Thus, the majority of the respondents held positive attitudes about CPE and CFA. Some of the affirmative responses they cited include:

1. Yes, pidgin is satisfactory as it is a majority language.

2. Yes, because it constitute codes of communication, but it would first and foremost be standardised.

3. It is our identity.

4. Good for people from different linguistics backgrounds (Abongdia, 2014).

The positive attitudes of the majority group about CPE are evident in their responses. Their attitude showed that the use of CPE was a form of social identity (Myers-Scotton, 2006; as cited in Abongdia, 
2014) among Anglophone Cameroonians, especially. Consequently, many view this variety as language of intimacy, socialisation, and identification as it is used across linguistic boundaries in Cameroon as well as for better comprehension and self-expression (Abongdia, 2014). Thus, very few people in Cameroon speak Standard English (defined in exogenous standard norms) as the use of CPE is a common practice. Mbangwana (1983, p. 87) underscored the imperativeness of CPE in Cameroon as it is essential to the indigenes no matter their educational, linguistic, and social backgrounds:

Pidgin English is very crucial as a communication bridge, for it links an Anglophone to a Francophone. It also links an Anglophone to another Anglophone, an educated Cameroon to another educated one, a non-educated Cameroonian to another non-educated one, and more importantly an educated Cameroonian to a non-educated one.

The remaining $26.7 \%$ who held negative attitudes toward both CPE and CFA also cited some responses:

1. I don't like them because they spoil our English and French languages.

2. I don't speak these varieties because I don't like them. I am unhappy with it.

3. No, it is degrading (Abongdia, 2014).

The above responses are direct reflection of the reason why CPE and CFA have been stigmatised by some Cameroonians who even see these languages as languages used by people who are not fluent or struggle with both English and French. Accordingly, the up-and-coming middle class Cameroonians discourage their children from speaking CPE; this is in consonance with Blommaert's (2006) notion about how language ideologies become entrenched within the wider society. According to Abongdia (2006) "they felt that this variety interfered in the English language and the children may end up speaking 'poor English' or non-Standard English...” In Ghana, Pidgin English (especially GhPE) is more stigmatized than in Nigerian and Cameroon (Schmidt \& Magnus, 2011). A lot of people are of the view that the use of Pidgin English has the tendency of ruining one's proficiency of Standard English. GhaPE is mostly blamed for the falling standard of the usage of English language in Ghanaian schools. Mr. J. H. Mensah, a senior minister of state in the Kufour administration, is reported to have attributed the poor performance of students in English language in some second cycle institutions to the blatant use of Pidgin English on the part of both some students and teachers (21 February 2005 Daily Graphic, cited in Adika, 2012). GhaPE is consequently not encouraged in most Ghanaian educational institutions. Dako (1999) drawing on the work of Huber (1999) has stated that Pidgin has never played any major role in the linguistic repertoire of Ghana. It has always been considered a foreign phenomenon that migrated with immigrants from mainly Liberia (Kru Brofo [Kru English]), and Nigeria (Abongo Brofo [Barracks Pidgin]), and Pidgin spoken by the Nsumfo ("Water People")—Nigerians who were trading in Ghana till 1969 when the Aliens Compliance Order was issued (Dako, 1999).

\subsection{Gender}

In the latter part of 1960 and the early 1970s, a pidgin started in the high-prestige cosmopolitan coastal secondary schools in Ghana. From this level, the speakers took it to the tertiary institutions. Thus, this 
phenomenon of SP started in the prominent coastal male secondary schools in Ghana and migrated to the tertiary institutions. Apparently, notably among them were Adisadel College, St. Augustine College, and Mfantsipim School. Around this same period-late 1960 and early 1970 soldiers were seen on the streets speaking pidgin as they blatantly and assertively exhibited their power (Dako, 1999). According to Dako (1999) Student Pidgin developed in this environment. This code, therefore, suggested power, "macho" behaviour (Dadzie, 1985). In a study conducted by Tawiah (1998) which used 50 males and 50 females randomly selected from the Halls of Residence of University of Ghana, it was found that only 3 of the 50 female participants admitted knowledge of SP. This according to Dako (1999) makes Student Pidgin a gender specific code. Out of the 50 male participants, 47 said they spoke pidgin; and 3 claimed they did not have knowledge on pidgin. Out of these 3 who did not speak pidgin, 2 were older mature students who did not pass through the normal secondary education system where SP is reported to have migrated from. The third respondent was a born-again Christian who claimed that SP, which is frivolous, "deflected from serious academic studies" (Tawiah, 1998; cited in Dako, 1999). Schmidt and Huber (2011) in their paper of Pidgin English in early highlife recordings of Ghanaian musicians/bands noted that Pidgin English was only used by male singers. Some of these songs/musicians/bands include E.T. Mensah's "Day by Day", The Red Spots Band's "Coffee and Tea”, Ramblers Dance Band's "Work and Happiness", and King Bruce and Black Beats' "The Queen's Visit". These substantiations hence make GhaPE and SP a male-dominant phenomenon. However, this does not necessary mean that the situation still remains the same presently. According to Abdullahi-Idiagbon (2010) Nigerian youth, mostly males use certain terminologies on the various university campuses to gossip about their female counterparts:

1. Honestly, the babe fine no be small (Honestly, the lady is charmingly beautiful).

2. The baby na cowbell (The lady is big-breasted).

3. Tear im wrapper (Have sex with her).

4. You sweet Omo (You are very beautiful, young lady) (Abdullahi-Idiagbon, 2010).

Moreover, touts, hoodlums and area boys use NPE a lot. These speakers are mostly illiterate males from Lagos. Their version is highly vulgar:

1. That guy too dey yarn dust (That young man doesn't talk sensibly).

2. Why you step me now, dem fence your eyes (Why did you step on me, Are you blind?) (Abdullahi-Idiagbon, 2010).

Conversely, these cases alone do not suggest that NPE is dominated by male speakers. According to Ndimele (2011) there is ample evidence that NP is now a Creole which has acquired native speakership in most of the Delta areas of Warri, Sapele, Port Harcourt, and Benin. This information is corroborated by Abdullahi-Idiagbon (2010): "Over the years, NPE has expanded, stabilized and probably creolized". When a code is creolized, it becomes the mother tongue of some communities. The implication is that all and sundry speaks it. Therefore, NPE is not wholly dominated by males; but by females as well. It is mostly used by market women, hair dresses and women in other artisanal vocations. Neba et al. (2006) 
have also reported that CPE is no longer a makeshift language; it has been creolized making it a mother tongue to a lot of Cameroonian children. About $52 \%$ of Cameroonians are females. Women again, constitute about $89 \%$ of the actors in the informal sector. Most of these women are not literate in either English or French. They thus, resort to CPE for trading activities. Thus, CPE just like NPE and unlike GhaPE is dominated by both males and females.

\subsection{Domains of Language Use}

Fishman (1972) has stated that the factors which influence the concept of domain are topic, role relation, and locale. The topic is the regulator of language use in multilingual setting. The role relation means that languages we use are determined by the interlocutors we communicate with; while the locale is the influence that the setting of the conversation has on the language. Ofulue (2011) in juxtaposing NP, GhaP and CamP has pointed out that all the three varieties of Pidgin do not play any significant role in formal education in Nigeria, Ghana, and Cameroon; though, they are widely used informally. As NP is predominantly used in mass media (for example, in radio transmission on Wazobia FM) and political campaigns, both GhaP and CamP are rarely used in this domain - mass media. In administrative work (e.g., government, parliament, national/state assemblies), she has reported that the three varieties of pidgin do not play any major role in the formal context in the three countries. But in the informal context, NP and CamP are widely used in Nigeria and Cameroon correspondingly. Again, while NP and CamP are fairly used in religious matters in Nigeria and Cameroon, GhaP is not used at all in this domain. However on commerce, all the three varieties have been reported to have been employed predominantly in the three countries-Nigeria, Ghana, and Cameroon (Ofulue). According to Neba et al. (2006) CPE is employed across the board, in that it appears in all functional domains in Cameroon. As it is extremely high in domains such as: religion, trade, humour, and intimacy; is high in political campaigns, secret, literacy topics, and science and technology; and low in education, mass media, administration, literature and performing arts, politics and national and cultural identity. Neba et al. have subsequently argued that CPE should be adopted as a medium of instruction in urban centres, since it is a language of wider communication. Contrary to the situation in Nigeria and Cameroon, Pidgin has never played any momentous function in the linguistic repertoire of Ghana (Dako, 2002). GhaPE has not got any formal recognition in Ghana. Though quite a number of unpublished Masters and $\mathrm{PhD}$ theses in various research institutions have focused on this variety, the only comprehensive published book remains Huber's Ghanaian Pidgin English in its West African Context (Adika, 2012). In fact, most educated individuals have opinionated that it is the cause for the fallen standard of English.

\section{Conclusion}

This work has looked at the review of some papers on West African Pidgin Englishes. The papers used, were drawn from three West African states of Ghana, Nigeria and Cameroon. Specifically, certain leading sociolinguistic variables-attitudes, code switching, gender and domains of language 
use-found in these works have been identified and discussed. It is important to note that these New Englishes are not necessarily deviant forms; but they are right in their own context especially when they serve the linguistic needs of their respective communities.

\section{References}

Abdullahi-Idiagbon, M. S. (2010). The sociolinguistics of Nigerian Pidgin English in selected university campuses in Nigeria. Ife Studies in English Language, 8(1), 50-60.

Abongdia, J.-F. A. (2014). Ideologies and attitudes towards Pidgin English in Cameroon. $\begin{array}{lllll}\text { Mediterranean } \quad \text { Journal } & \text { Social }\end{array}$ https://doi.org/10.5901/mjss.2014.v5n7p601

Adika, G. S. K. (2012). English in Ghana: Growth, tensions, and trends. International Journal of Language, Transilation and Intercultural Communication, 1(1), 151-166. https://doi.org/10.12681/ijltic.17

Akinnaso, N. F. (1989). One nation, four hundred languages: Unity and diversity in Nigeria's language policy. Language Problems and Language Planning, 13, 133-146. https://doi.org/10.1075/lplp.13.2.03aki

Amoako, Joe K. Y. N. (1992). Ghanaian Pidgin English: In search of synchronic, diachronic, and sociolinguistic evidence (Unpublished $\mathrm{PhD}$ dissertation). University of Florida at Gainsville.

Avram, A. A. (2003). Ghanaian Pidgin English in Its West African context: A socio-historical and structural analysis by Magnus Huber. Language in Society, 32(2), 285-289. Cambridge: Cambridge University Press. Retrieved September 23, 2014, from http://www.jstor.org/stable/4169260

Ayafor, M. (1996). An orthography for Kamtok. English Today, 12(4), 53-57. https://doi.org/10.1017/S0266078400009317

Bamgbose, A. (1982). Languages in contact: Yoruba and English in Nigeria. Education and Development, 2(1), 329-341.

Blommaert, J. (2006). Language policy and national identity. In T. Ricento (Ed.), An introduction to language policy: Theory and method. Oxford: Blackwell Publishing.

Brann, C. M. B. (1985). Language policy, planning and management in Nigeria: A third eye view. Sociolinguistic, ZVII, 30-32.

Brato, T., \& Jansen, S. (2008). You used to gerri in yer fishnets, now you only gerri in yer nightdress: Regional and supra regional accents in English rock songs. Presentation at the Thirteenth International Conference on Methods in Dialectology, 04 August 2008, Leeds.

Coester, M. (1998). Language as a product of cultural contact. Ntam, Journal of African Music and Popular Culture. Retrieved July 31, 2011, from http://www.unihildesheim.de/ntama

Coulmas, F. (Ed.). (1997). The handbook of sociolinguistics. MA, USA: Blackwell.

Dadzi, A. B. K. (1985). Pidgin in Ghana: A rhetorical consideration of its origin and development. In F. 
O. Ugboajah (Ed.), Mass Communication, Culture and Society in West Africa (pp. 113-121). Munich: Hans Zell.

Daily Graphic 21 February. (2005).

Dako, K. (1999). Pidgin as a gender specific language in Ghana. Journal of Ghana English Studies Associotion, 1(1).

Decamp, D. (1971). Introduction: The study of Pidgin and Creole languages. In R. Appel, \& P. Muysken (Eds.), Language, Contact and Bilingualism (1987). London: Edward Arnold.

Deubar, D. (2005). Nigerian Pidgin in Lagos-Language contact, variation and change in an African urban setting. London: Battle Bridge Publications.

Edwards, J. (1994). Multilingualism. London: Routledge. https://doi.org/10.4324/9780203430927

Elugbe, B. (1995). Nigerian Pidgin: Problems and prospects. In A. Banjo, \& T. Andrew (Eds.), New Englishes. Ibadan: Mosurp Publishers.

Elugbe, B. O., \& Omamor, A. P. (1991). Nigerian Pidgin: Background and Prospects. Ibadan: Heinemann Educational Books.

Fishman, J. (1972). The relationship between micro and macro-sociolinguistics in the study of who speaks what language and to whom and when. In Pride, \& Holmes (Eds.), Sociolinguistics. Harmondsworth: Penguim.

Holmes, J. (2001). An introduction to sociolinguistics. UK: Longman.

Huber, M. (1999). Ghanaian Pidgin English in its West African context. Amsterdam: John Benjamins. https://doi.org/10.1075/veaw.g24

Hudson, R. A. (1990). Sociolinguistics. London: Cambridge University Press.

Ihemere, K. U. (2006). A basic description and analytic treatment of noun clauses in Nigerian Pidgin. Nordic Journal of African Studies, 15(3), 296-313.

Jowitt, D. (1994). Nigerian English usage: An introduction. Nigeria: Longman.

Kamtok (Pidgin) is gaining ground in Cameroon. (2006). In E. Chia (Ed.), African Linguistics and the Development of African Communities. Senegal: CODESEIA.

Kamtok: The ultimate unifying language for Cameroon. (2000). The Carrier Pidgin, 28, 1-3.

Kreyer, R., \& Mukherjee, J. (2007). The style of pop song lyrics: A corpus-linguistic pilot study. Anglia, 125(1), 31-58. https://doi.org/10.1515/ANGL.2007.31

Kroskrity, P. (2000). Language ideological perspective. In P. Kroskity (Ed.), Regimes of Language (pp. 1-34). Oxford: American Research Press.

Mbangwana, P. N. (1983). Political language and orality in African literature. 3rd Annual International Conference on African Literature and English Language.

McArthur, T. (1998). The English language. Cambridge: CUP.

Miethaner, U. (2005). I can look through muddy water: Analyzing earlier African American English in blues lyrics (BLUR). Frankfurt am Main: Lang.

Myers-Scotton, C. (2006). Multiple voices: An introduction to bilingualism. Oxford: Blackwell Published by SCHOLINK INC. 
Publishing.

Ndimele, R. I. (2011). Communication problems of Nigerian Pidgin speakers. A paper presented at the Summer Conference Organized by the Society for Pidgin and Creole Linguistics, Accra, Ghana.

Neba, Ayu'nwi N., Chibaka, E. F., \& Atindogbe, G. G. (2006). Cameroon Pidgin English (CPE) as a tool for empowerment and national development. African Study Monographs, 27(2), 39-61.

Nettey, R. C. (2001). Linguistic interaction among male students at the University of Ghana-Legon: A Micro Study (Unpublished Long Essay). Department of English.

Obiechnina, D. (1984). Towards the classification of Nigerian Pidgin English. London: Longman.

Ofulue, C. I. (2011). Nigerian Pidgin and West African pidgins: A sociolinguistic perspective. A paper presented at the Summer Conference Organized by the Society for Pidgin and Creole Linguistics, Accra, Ghana.

Quirk, R., Greenbaum, S., Leech, G., \& Svartvik, J. (1985). A comprehensive grammar of the English language. London: Longman.

Rickford, J. R. (1991). Pidgins and Creoles. In W. Bright (Ed.), Oxford International Encyclopedia (Vol. 3, pp. 224-232).

Schmidt, S., \& Huber, M. (2011). Investigating the history of Pidgin [in] English early highlife recordings from Ghana. A paper presented at the Summer Conference Organized by the Society for Pidgin and Creole Linguistics, Accra, Ghana.

Schneider, G. (1963). First steps in Wes-kos. Harford Studies in Linguistics, 6(4), 11-81.

Schröder, A. (2003). Status, functions and prospects of Pidgin English: An empirical approach to language dynamics in Cameroon. Gunter Narr Verlag: Tübingen.

Tawiah, B. (1998). Pidgin English in Ghana: An investigation into the gender predominance. A case study of students of the University of Ghana (Unpublished Long Essay). Department of English.

The language of the educated male elite. (2002). Research Review, 18(2), 53-62.

Todd, L. (1990). Pidgins and Creoles, new edition. London: Routledge and Kegan Paul.

Trudgill, P. (1983). Acts of conflicting identity: The sociolinguistics of British pop-song pronunciation.

In P. Trudgill (Ed.), On Dialect: Social and Geographical Perspective (pp. 141-160). Oxford: Blackwell.

Weber, J., \& Horner, K. (2012). Introducing multilingualism: A social approach. London: Routledge. Retrieved from http://www.hawaii.edu/satocenter/langnet/definitions/cameroon.html

\section{Notes}

Note 1. Tok Pisin (also called Pisin, New Guinea Pidgin English or Neo-Melanesian) is an English-based pidgin of Papua New Guinea, with 50,000 first-language speakers and 2,000,000 second-language speakers reported in 1982 (Rickford, 1991, p. 232).

Note 2. Krio is an English-based Creole of Sierra Leone, with 350,000 or more first-language speakers reported in 1987, including 247,000 in communities in Freetown and on the Peninsula, the Banana 
Islands, and York Island, and in Bonthe: used by detribalized Sierra Leoneans and as a lingua franca throughout Sierra Leone. It is also spoken by small numbers in Senegal, in Guinea, on Fernando Po Island, Equatorial Guinea, and in Bathhurst, Gambia (Rickford, 1991, p. 230).

Note 3. Sango (also spelt Sangho) is a Creole language based on Ngbandi, with 200,000 mother-tongue speakers reported in 1987, mainly in the Central African Republic, but also in Zaire, Chad, and Cameroon (Rickford, 1991, p. 230).

Note 4. Kamtok is the pidginised English of Cameroon. This English-related language has been a lingua franca in the country since at least the 1880s. The 35-year period since 1966 has seen dramatic changes in the attitude of speakers towards the language. Speakers have always recognised the usefulness of the language but, in early writings, it was frequently referred to as "Bad English", "Broken English" and "Bush English". Today, due mainly to its extended use in Churches and on Radio and Television, it is becoming known as Kamtok from Cameroon Talk, and is taking its place as a recognised medium of interaction.

Note 5. The Bafut language, Fut, is an Eastern Grassfields language of the Niger-Congo languages, and related to Bamum. Oral tradition traces dynastic origins to the Ndobo or Tikari areas. It is spoken by people of Bafut Subdivision, Tuba, in the division of Mezam and in the division of Metchum in Northwest Province, Cameroon.

Note 6. WAZOBIA FM is a radio station in Port Harcourt, and Lagos, Nigeria, that is dedicated to broadcasts in Nigerian Pidgin English only. It is the only radio station in Nigeria that uses NP in its transmission, including news broadcasts. It was established in 2007 and its target audience includes both literate and non-literate in English. Most literate users of NP post comments on the station's Facebook page. In the absence of a standard orthography, the station has devised its own writing system for NP. 